DOROTA KOWALSKA

\title{
ZAWARTOŚĆ CHLOROPROPANODIOLI W KWASOWYCH HYDROLIZATACH BIALEK ROŚLINNYCH I SOSACH SOJOWYCH
}

\begin{abstract}
Streszczenie
W wielu krajach azjatyckich sosy sojowe są tradycyjnymi, od wieków stosowanymi przyprawami smakowo-zapachowymi dodawanymi do żywności w toku produkcji wyrobów spożywczych, jak i przyprawami stołowymi do indywidualnego uznania konsumenta. Światowa roczna produkcja sosu sojowego wynosi ponad $10 \mathrm{mld}$ litrów (10 $\mathrm{mln}$ ton). Największym producentem sosu sojowego są Chiny (5 mln ton). Chiny są również głównym jego eksporterem (ponad 94 tys. ton). Obserwowana jest ekspansja tych produktów na rynki krajów Europy i Ameryki. Stosuje się dwie główne grupy metod produkcji sosów sojowych: fermentacyjne i polegające na kwasowej hydrolizie białek. Produkcja sosów sojowych według technologii tradycyjnych (metody fermentacyjne) jest długotrwała, a przez to kosztowna. Rozwijane są zatem technologie polegające na fermentacji "przyspieszonej” bądź wykorzystujące surowce semisyntetyczne (kwasowe hydrolizaty białek roślinnych - HVP). Na przełomie lat 70. i 80. XX w. stwierdzono obecność w HVP i produkowanych na bazie HVP sosach sojowych 3-monochloropropanodiolu (3-MCPD), a potem obecność 2-MCPD, dichloropropanoli (DCP) oraz estrów chloropochodnych propanodioli i propanolu z kwasami tłuszczowymi. Związki te są szkodliwe dla zdrowia, a spożywane w większych ilościach wywołują zmiany rakotwórcze, choroby nerek i zaburzenia reprodukcyjne. W niniejszej pracy przedstawiono przegląd literaturowy dotyczący produkcji sosów sojowych. Celem tego przeglądu było zebranie informacji dotyczących technologii produkcji sosów sojowych. Szczególną uwagę zwrócono na obecność 3-MCPD. Omówiono regulacje prawne i metody analityczne dotyczące oznaczania 3-monochloropropanodiolu.
\end{abstract}

Słowa kluczowe: HVP, kwasowe hydrolizaty białkowe, sos sojowy, chloropropanodiole, chloropropanole, 3-MCPD

\section{Wprowadzenie}

Sosy sojowe produkowane są w krajach wschodniej Azji i występują pod nazwami: Shoyu, Tamari Shoyu (Japonia), Jiang You (Chiny), Ketjap/Kecap (Indonezja),

Dr D. Kowalska, Katedra Chemii, Wydz. Nauk o Żywności, Szkoła Główna Gospodarstwa Wiejskiego wWarszawie, ul. Nowoursynowska159 C,02-776Warszawa.Kontakt:dorota_kowalska@sggw.pl 
Kicap (Malezja), Kanhang/Ganjang (Korea), Toyo (Filipiny), Si-iw (Tajlandia), Nuoc tuong, Xi dau (Wietnam). Charakteryzują się ostrym, słonym smakiem i stanowią jedną z ważniejszych przypraw stosowanych w wymienionych krajach do produkcji żywności i potraw domowych [15-17, 43, 47]. Skład sosów sojowych i ich walory smakowo-zapachowe zależą od technologii produkcji. Obok związków kształtujących te walory sosy sojowe mogą zawierać związki szkodliwe dla zdrowia, w tym chloropochodne propanolu. W niniejszej pracy przedstawiono stan wiedzy dotyczący produkcji sosów sojowych i obecności w nich chloropropanodioli i chloropropanoli.

\section{Fermentacyjne technologie otrzymywania sosów sojowych}

Produkcja sosów sojowych według tradycyjnych metod ich wytwarzania składa się zwykle z trzech etapów (rys. 1A). Pierwszy to wytworzenie tzw. koji, który polega na poddawaniu mieszaniny odtłuszczanych granulatów soi i prażonej pszenicy $(1: 1 \mathrm{~m} / \mathrm{m})$, ostudzonych i o naturalnej wilgotności, procesowi kilkudniowej fermentacji w obecności starterów (Aspergillus oryzae i/lub Aspergilus sojae). Stosunki ilościowe używanych surowców zależą od rodzaju wytwarzanego sosu sojowego i stosowanego oprzyrządowania. Proces fermentacji przebiega w fazie stałej, na drewnianych tacach w temp. ok. $25{ }^{\circ} \mathrm{C}$. Po $2 \div 3$ dniach fermentowana warstwa grubości $3 \div 5 \mathrm{~cm}$ pokrywa się żółto-zieloną pleśnią, a cały produkt tego etapu jest określany w Japonii terminem koji. Niezwykle istotne dla późniejszej jakości produktu jest regularne mieszanie warstw koji, tak aby temperatura nie przekraczała $25 \div 28^{\circ} \mathrm{C}$ oraz wcześniejsza staranna selekcja najlepszych preparatów szczepów $A$. oryzae i $A$. sojae. W tradycyjnych technologiach wszystkie czynności wykonywano ręcznie, obecnie wykonuje się je mechanicznie [15], co, zdaniem wielu technologicznych konserwatystów z rejonów wschodniej Azji, wpływa negatywnie na jakość produktu finalnego.

W drugim etapie uzyskany produkt miesza się z solanką $(\sim 20 \%)$ i tak przygotowany zacier, określany terminem moromi, zawierający $17 \div 19 \%$ soli poddawany jest tzw. fermentacji solankowej (brine fermentation). Swoisty autostarter (koji) zawierający powstałe w nim bakterie (Pediococcus halophilus) i drożdże (Zygosaccharomyces rouxii, Candida sp., Candida versatilis, Candida etchellsii) powoduje, że fermentacja brine jest wyjątkowo złożonym, głównie o charakterze fermentacji kwasowoalkoholowej (kwas mlekowy, etanol oraz inne produkty) i długotrwałym $(6 \div 9$ miesięcy) procesem. W końcowej fazie fermentacji mieszanina może być wzbogacana w preparaty regulujące przebieg procesu tak, aby pH układu nie zmniejszało się poniżej 5,0, a temperatura nie wzrosła powyżej $28^{\circ} \mathrm{C}$. Stosowane jest także napowietrzanie. Stężenie etanolu po fermentacji wynosi $2 \div 3 \%$ i może być wcześniej regulowane dodatkiem preparatów immobilizowanych drożdży [24]. Podczas fermentacji enzymy 
A

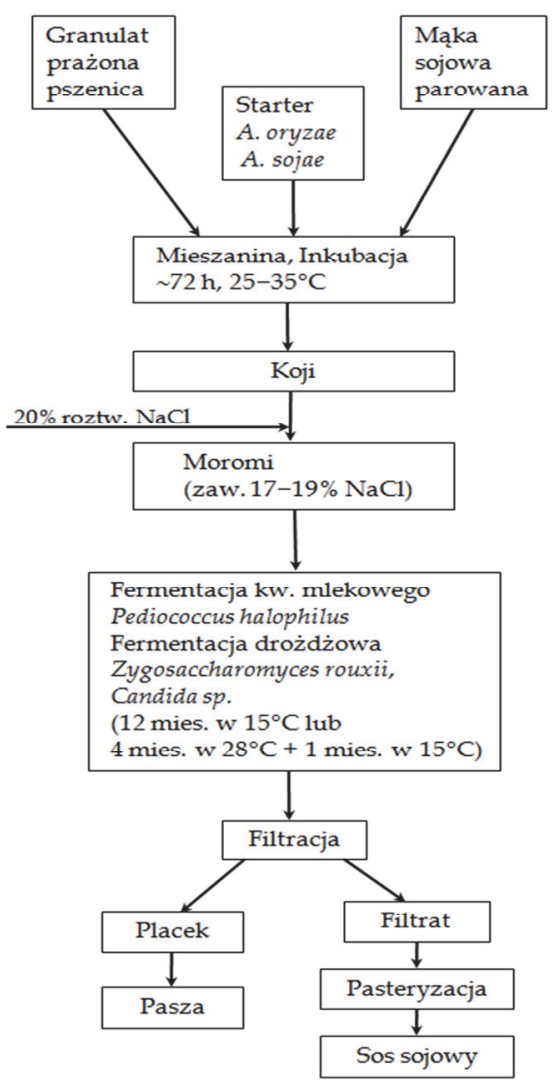

Objaśnienia / Explanatory notes:

A

Granulat, prażona pszenica / Granulate, roasted wheat

Mąka sojowa parowana / Soy flour, steamed

Mieszanina, inkubacja / Mixture, incubation

Fermentacja kw. mlekowego / Lactic acid fermentation

Fermentacja drożdżowa / Yeast fermentation

Filtracja / Filtration

Placek, pasza / Cake, feed

Filtrat / Filtrate

Pasteryzacja / Pasteurization

Sos sojowy / Soy sauce
B

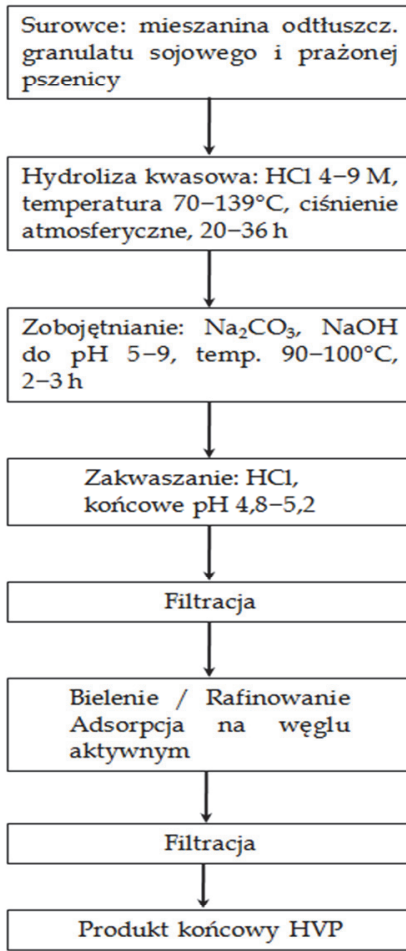

Surowce / Raw materials

Mieszanina odtłuszcz. granulatu sojowego i prażonej pszenicy / Defatted mixture of soy granulate and roasted wheat

Hydroliza kwasowa / Acid hydrolysis

Temperatura / Temperature

Ciśnienie atmosferyczne / Atmospheric

pressure

Zobojętnianie / Neutralization

Zakwaszanie / Acidification

Końcowe $\mathrm{pH}$ / Final pH

Filtracja / Filtration

Bielenie, rafinowanie, adsorpcja na węglu

aktywnym / Bleaching, refinement, adsorption

on activated carbon

Produkt końcowy HVP / Final product HVP

Rys. 1. Schematy: A. Produkcji sosu sojowego. B. Produkcji kwasowych hydrolizatów białek roślinnych HVP

Fig. 1. Flow-charts: A. Production of soy sauce, B. Production of acid hydrolyzed vegetable proteins HVP Opracowano na podstawie / Based on: [20,35]. 
proteolityczne z koji hydrolizują białka sojowe i pszeniczne, z których uwalniane są aminokwasy i niskocząsteczkowe peptydy. Zawarta w surowcach skrobia jest przekształcana w cukry proste, które dalej fermentowane są do kwasu mlekowego, etanolu i dwutlenku węgla. W trakcie procesu powstaje wiele $(>150 \div 200)$ lotnych i trudno lotnych związków o specyficznych walorach smakowo-zapachowych. Ich stężenia wynoszą zwykle od kilku do kilkuset ppm. Są to izomeryczne alkohole, furfurole i furanony, laktony, ketony, merkaptanole. Analitycy zwracają uwagę na obecność HEMF (4-hydroksy-5-etylo-5-(2H)-furanonu) i jego pochodnych), HDMF (4-hydroksy-2,5-dimetylo-3(2H)-furanonu), HMMF (4-hydroksy-5-metylo-3(2H)furanonu), a także 4-EG (4-etylogwajakolu, 4-etylo-2-metoksyfenolu), 4-etylofenolu i wielu innych związków tworzących "bukiet" smakowo-zapachowy sosów sojowych. Szczegółową analizę związków determinujących smak i zapach fermentowanych w fazie stałej 5 chińskich sosów sojowych podali Yanfang i Wenyl [59]. Podobną pracę z chemometrycznym opracowaniem wyników oraz analizą sensoryczną opublikowali Feng i wsp. [14]. Sun i wsp. [45] przeprowadzili analizy chemiczne 12 rodzajów chińskich sosów sojowych otrzymywanych w technologii HSDSF (High-Salt-Diluted State Fermentation) przy użyciu metody HS-SPME-GC-MS. Zidentyfikowano w lotnych frakcjach sosów sojowych 80 różnych składników (alkohole, estry, aldehydy i ketony, kwasy, furany, fenole, pirazyny i inne), z których 34 było wspólnych dla każdego sosu. Wyniki oznaczeń pozwoliły na przeprowadzenie według metodyki PCA (Principal Component Analysis) podziału badanych sosów na 4 grupy. Zgodnie z metodyką opracowaną przez Tsenga i wsp. [49], występujące w sosach aminokwasy kształtujące smak podzielono na grupy wnoszące deskryptory określane jako: cierpki, słodki, gorzki, "umami", "MSG-like" (MSG - glutaminian monosodowy).

Analizy lotnych związków z tych sosów wykazały obecność 82 różnego rodzaju związków chemicznych [59] należących do grup: alkoholi (12 związków), kwasów (16), estrów (5), aldehydów (10), ketonów (10), fenoli (5), związków heterocyklicznych (17), alkanów (6), węglowodorów aromatycznych (1). Większość tych lotnych związków determinujących walory smakowo-zapachowe została zidentyfikowana. W trakcie procesu produkcyjnego, podczas fermentacji alkoholowej powstają także niewielkie ilości $(15 \div 70 \mathrm{ppb})$ karbaminianu etylu, powszechnie znanego groźnego zanieczyszczenia procesowego produktów gorzelniczych [55]. Z drugiej strony podkreślane są korzystne cechy sosów sojowych wynikające $\mathrm{z}$ ich działania antymutagennego i aktywności przeciwutleniającej [54]. Rygorystyczne zarządzenia dotyczące produkcji sosu sojowego obowiązujące np. w Japonii wymagają, aby mieszanina po fermentacji podlegała obowiązkowo starzeniu (aging), po czym następowałaby filtracja i pasteryzacja oraz konfekcjonowanie. Są to operacje stanowiące trzeci etap produkcji sosu sojowego [20]. We współczesnych technologiach fermentacyjnych sosu sojowego starzenie jest często pomijane [35], co prowadzi do sporów proceduralnych 
i terminologicznych. Schematy technologiczne przykładowych fermentacyjnych procesów produkcji sosu sojowego w wersji tradycyjnej i współczesnej (przyśpieszonej) przedstawiono w pracach $[15,20,35,45,47]$.

\section{Produkcja sosu sojowego z kwasowych hydrolizatów białek roślinnych (HVP)}

Technologie fermentacyjne produkcji sosu sojowego są bardzo czasochłonne, a przez to drogie. Od dawna poszukiwano metod redukcji kosztów wytwarzania sosu sojowego, modyfikując i mechanizując etapy fermentacji. Dodatkowo stwierdzono, że równolegle $\mathrm{z}$ fermentacją masy moromi $\mathrm{w}$ wyniku działania enzymów proteolitycznych pochodzących z koji w masie poreakcyjnej znacząco wzrasta zawartość wolnych aminokwasów. W typowym japońskim sosie sojowym Koikuchi (Koikuchi soya sauce) udział poszczególnych aminokwasów w całkowitej ich ilości jest następujący: ok. $22,5 \%$ kwasu glutaminowego, 10,5 \% kwasu asparaginowego, 7,3 \% leucyny, po $6,5 \%$ lizyny i proliny, po 5,5 $\pm 0,2 \%$ seryny, waliny i ornityny, po $4,4 \pm 0,4 \%$ fenyloalaniny, treoniny, izoleucyny i alaniny. Zawartość pozostałych aminokwasów nie przekracza $1 \div 2 \%$. Przy nasilającej się presji ekonomicznej oczywista staje się zatem możliwość zastąpienia w produkcji sosu sojowego procesów fermentacyjnych procesami chemicznymi. Przeprowadzono kwasowe hydrolizy $(4 \div 9$ molowy $\mathrm{HCl}$, temp. 90 $\div 130{ }^{\circ} \mathrm{C}$ ) mieszanin granulatów sojowych i pszenicznych, w wyniku których w ciągu kilkudniowej operacji produkcyjnej otrzymywano hydrolizaty (HVP), z których wytwarzano handlowe sosy sojowe mniej lub bardziej przypominające oryginalne wyroby otrzymywane technologiami fermentacyjnymi [31]. Przykładowy schemat technologiczny wytwarzania HVP przedstawiono na rys. $1 \mathrm{~B}$, nieco inne rozwiązania przedstawiono w publikacjach $[5,15]$. Charakterystyki chemiczne i sensoryczne takich hydrolizatów przedstawiane są w publikacjach $[1,2]$ ze względu na to, że HVP stosowane są nie tylko do produkcji sosu sojowego, ale także do wielu innych regionalnych i etnicznych produktów spożywczych. Stosowanie HVP do produkcji sosu sojowego bądź dodawanie HVP do fermentacyjnych sosów sojowych od początku napotykało na opór i protesty legislacyjne (Japonia, Chiny) organizacji stanowiących prawo żywnościowe w różnych krajach [8]. Jest to tym bardziej zasadne, że istniały obawy stosowania i innych niż sojowe hydrolizatów kwasowych produkowanych np. z otrąb ryżowych [25]. Należy zaznaczyć, że istnieją metody, polegające na analizie lotnych związków w fermentowanych i wytwarzanych z HVP oraz ich mieszaninach lub na podstawie monitorowania zawartości kwasu lewulinowego (4-oksowalerianowego), oznaczania obecności HVP w sosach sojowych [32, 42, 45]. Względy ekonomiczne i rynek wymusiły jednak to, że wyroby etykietowane jako sos sojowy, a produkowane na bazie HVP bez podawania tej informacji znajdują się w handlu. 
Odrębnym problemem są nieliczne jak dotychczas wdrożone technologie wytwarzania sosów sojowych typu instant (w postaci proszków) produkowane przez rozpyłowe suszenie koncentratów sosu sojowego.

Według szacunków z 2015 roku [31] roczna światowa produkcja sosu sojowego wynosi ok. 10 mld litrów. Konsumpcja sosu sojowego w przeliczeniu na mieszkańca wynosi rocznie w USA 0,8 litra, a w Japonii 9 litrów. Szacuje się, że dzienna konsumpcja sosu sojowego w Chinach wynosi $9 \mathrm{ml}$ na osobę. Jak podają Feng i wsp. [14] oraz Sun i wsp. [45], roczna produkcja sosu sojowego w Chinach wynosi ok. $5 \mathrm{mln}$ ton. W 2011 roku głównymi eksporterami sosu sojowego były Chiny (94143 tony) i Holandia (34673 tony), a głównymi importerami USA (59298 ton), Hong Kong (22519 ton) i Wielka Brytania (19576 ton). W ostatnich latach obserwowana jest znacząca ekspansja tego produktu na rynki europejskie, w tym także na rynek polski [45, $46]$.

\section{3-MCPD w sosach sojowych - regulacje prawne}

$\mathrm{Na}$ przełomie lat 70. i 80. ubiegłego wieku stwierdzono obecność 3-chloropropano-1,2-diolu (3-MCPD) w kwasowych hydrolizatach białek roślinnych (HVP) stosowanych do produkcji sosu sojowego [10, 51, 52]. Z czasem stwierdzono także obecność innych chloropochodnych propanoli i propanodioli. Związki tego typu są szkodliwe dla zdrowia, a spożywane w większych ilościach wywołują zmiany rakotwórcze [48].

Należy zwrócić uwagę, że HVP i sosy sojowe są jedynymi produktami spożywczymi objętymi regulacjami prawnymi Unii Europejskiej w odniesieniu do zawartości 3-MCPD. W Rozporządzeniu nr 1881/2006, przyjętym 20 grudnia 2006 roku przez Komisję Kodyfikacyjną UE, ustanowiono tzw. Dopuszczalne Dzienne Spożycie 3-MCPD w HVP lub sosie sojowym (DDS) na poziomie $2 \mu \mathrm{g} / \mathrm{kg}$ masy ciała konsumenta. Maksymalna dopuszczalna zawartość 3-MCPD w HVP i sosie sojowym wynosi do $20 \mu \mathrm{g} / \mathrm{kg}$ masy produktu. Określony limit zawartości 3-MCPD został wyznaczony przy założeniu, że ciekły produkt zawiera $40 \%$ suchej masy, co odpowiada zawartości w niej 3-MCPD maksymalnie $50 \mu \mathrm{g} / \mathrm{kg}$ [41]. Liczne informacje o obecności chloropropanoli, chloropropanodioli, glicydolu oraz estrów tych związków z kwasami tłuszczowymi w różnych rodzajach żywności doprowadziły do wydania przez Komisję Europejską Zalecenia z dnia 10 września 2014 r. w sprawie monitorowania występwania w żywności 2- i 3-MCPD, ich estrów z kwasami tluszczowymi oraz glicydolu i jego estrów [60]. Należy podkreślić, że chloropropanodiole (3-MCPD, 2-MCPD), dichloropropanole (1,2 i 1,3 DCP) oraz glicydol znajdują się na liście OEHHA (Office of Environmental Health Hazard Assessment) jako związki powodujące raka i zaburzenia reprodukcyjne [40]. W tab. 1. podano informacje o maksymalnych, dopuszczal- 
nych zawartościach 3-MCPD i 1,3-DCP w HVP i w sosach sojowych w przepisach prawnych różnych krajów.

Tabela 1. Limity zawartości 3-MCPD i 1,3-dichloropropanolu (1,3-DCP) w HVP i sosach sojowych pochodzących z różnych krajów

Table 1. International maximum limits for 3-MCPD and 1,3-dichloropropanol (1,3-DCP) in HVP and soy sauces

\begin{tabular}{||l|c|c|l||}
\hline \multicolumn{1}{|c|}{$\begin{array}{c}\text { Kraj (Region) } \\
\text { Country (Region) }\end{array}$} & $\begin{array}{c}3-\mathrm{MCPD} \\
{[\mathrm{mg} / \mathrm{kg}]}\end{array}$ & $\begin{array}{c}1,3-\mathrm{DCP} \\
{[\mathrm{mg} / \mathrm{kg}]}\end{array}$ & \multicolumn{1}{|c|}{ Produkt / Product } \\
\hline Australia / Australia & 0,2 & 0,005 & Sos sojowy / Soy sauce \\
\hline Nowa Zelandia / New Zealand & 0,2 & 0,005 & Sos sojowy / Soy sauce \\
\hline Kanada / Canada & 1 & & Sos sojowy / Soy sauce \\
\hline Chiny / China & 1 & & HVP \\
\hline $\begin{array}{l}\text { Unia Europejska } \\
\text { European Community }\end{array}$ & 0,02 & & $\begin{array}{l}\text { HVP i sos sojowy } \\
\text { HVP and soy sauce }\end{array}$ \\
\hline Korea / Korea & 0,3 & & $\begin{array}{l}\text { Sos sojowy z HVP / Soy sauce } \\
\text { with HVP } \\
\text { HVP }\end{array}$ \\
\hline Malezja / Malaysia & 1 & & $\begin{array}{l}\text { Płyny spoż. z HVP / Liquid } \\
\text { foods with HVP } \\
\text { HVP }\end{array}$ \\
\hline Szwajcaria / Switzerland & 0,02 & & Sos sojowy / Soy sauce \\
\hline Tajlandia / Thailand & 1 & & HVP \\
\hline USA / USA & 1 & & HVP \\
\hline
\end{tabular}

Oznaczane w sosach sojowych zawartości 3-MCPD, 2-MCPD i 1,3-DCP są wynikami badań naukowych służących zazwyczaj monitorowaniu produktów rynkowych. Rzadziej dyskutowane są realne zagrożenia dotyczące zdrowia konsumentów. Przeprowadzone w 2011 r. w Nowej Zelandii badania zawartości 3-MCPD i 1,3-DCP w 125 próbkach głównie importowanych sosów sojowych [37] wykazały, że zdecydowana większość badanych próbek spełniała wymagania stawiane sosom sojowym pod względem zawartości w nich 3-MCPD. Stwierdzona w jednej próbce zawartość 3-MCPD wynosząca $2,5 \mathrm{mg} / \mathrm{kg}$ wskazuje, że dorosły konsument musiałby spożywać każdego dnia 57 g takiego sosu sojowego, aby osiągnąć graniczną wartość dopuszczalnego dziennego spożycia ( $2 \mu \mathrm{g} / \mathrm{kg}$ masy ciała). Byłaby to ilość wykraczająca poza stwierdzone $\mathrm{w}$ badaniach indywidualne spożycie sosów sojowych. Podobną opinię formułują Wong i wsp. [56] po oznaczeniu w latach $2000 \div 2002$ zawartości 3-MCPD w 421 próbkach sosów sojowych i ostrygowych pochodzących z sieci handlowej w Singapurze. 


\section{3-Monochloropropanodiol (3-MCPD) i inne chloropochodne propanodioli i propanoli w sosach sojowych - występowanie i metody oznaczania}

Metody oznaczania MCPD, DCP i glicydolu w produktach spożywczych dzielą się na pośrednie - wymagające otrzymywania pochodnych tych związków oraz bezpośrednie - niewymagające derywatyzacji. Większość publikowanych prac dotyczy metod pośrednich. Coraz częstsze w użyciu metody bezpośrednie, charakteryzujące się wysokimi wymaganiami aparaturowymi i szerokimi zbiorami wzorców analitycznych, są stosowane od ok. $6 \div 7$ lat $[19,30,37,58]$.

Metody pośrednie stosowane są od dawna. $\mathrm{Z}$ uwagi na to, że $\mathrm{w}$ większości próbek żywności MCPD, DCP i glicydol występują w postaci estrów z kwasami tłuszczowymi istotnym problemem metod pośrednich jest metodyka uwalniania (hydroliza lub częściej metanoliza) chloropropanodioli i dichloropropanoli z ich estrów. Stosowane transestryfikacje metanolem prowadzone są w środowisku alkalicznym (katalizator MeO$\mathrm{Na}$ - metoda Kuhlmana lub SGS) [30] albo w kwaśnym (katalizator kwas siarkowy(VI) - metoda Unilever) [13]. W obydwu metodach stosuje się przekształcanie glicydolu w stabilny 3-monobromopropan-1,2-diol (3-MBPD), aby zapobiec powstawaniu 3-MCPD z glicydolu. Następnie otrzymywane są pochodne MCPD i glicydolu z heptafluorobutyroimidazolem (HFBI), kwasem fenyloborowym (PBA) czy ketonami (aceton, 4-heptanon, cykloheksanon) według reakcji przedstawionych w innych publikacjach [4, 11, 28, 29]. Metoda Unilever uzyskała walidację American Oil Chem. Society i stała się oficjalną metodą (Official AOCS Method Cd 29a-13) tej organizacji [3]. Charakterystyki odczynników i metod stosowanych do otrzymywania pochodnych i dalszych oznaczeń wolnego 3-MCPD podali Lee i Khor [31]. Przeprowadzone przez zespół analityków z Centrum Badawczego firmy Nestle oznaczenia estrów 3-MCPD w oleju palmowym metodami: bezpośrednią i pośrednią wykazały, że otrzymywane w tych metodach wyniki są porównywalne [12].

Metody pośrednich oznaczeń MCPD, glicydolu i ich estrów z kwasami tłuszczowymi są $\mathrm{w}$ zasadzie uniwersalne i mogą być stosowane praktycznie do dowolnego asortymentu produktów spożywczych po właściwym przygotowaniu próbki do etapu otrzymania odpowiedniej pochodnej. W literaturze przedmiotu jest jednak wiele prac ukierunkowanych na dany rodzaj żywności. Na uwagę zasługuje wprowadzanie metod elektrochemicznych $\mathrm{w}$ połączeniu $\mathrm{z}$ osiągnięciami nanotechnologii do oznaczania i monitorowania zawartości 3-MCPD i innych chloropochodnych propanodioli i propanoli [44].

Zespół analityków z Politechniki Gdańskiej [26] przeprowadził analizę 17 procedur oznaczania 3-MCPD w sosach sojowych i produktach pochodnych. Wykonana metodą PROMETHEE (Preference Ranking Organization Method of Enrichment Evaluation) analiza pozwoliła na ustanowienie rankingu badanych procedur $\mathrm{w}$ aspekcie kryteriów: metrologicznego, ekonomicznego i środowiskowego. Otrzymane wyniki 
okazały się kompatybilne z wymaganiami stawianymi technologiom, które spełniają zasady zielonej chemii.

Tabela 2. Zawartość 3-MCPD w sosach sojowych i produktach pochodnych (PP) pochodzących z różnych krajów

Table 2. Content of 3-MCPD in soy sauces and derived products (PP) from different countries

\begin{tabular}{|c|c|c|c|c|c|}
\hline $\begin{array}{c}\text { Kraj } \\
\text { Country }\end{array}$ & \begin{tabular}{|c|} 
Granica \\
wykrywalności \\
Limit of \\
detection (LoD) \\
\end{tabular} & $\begin{array}{c}\text { Sosy sojowe i prod. } \\
\text { pochodne }(\mathrm{PP}) \\
\text { Soy sauces and related } \\
\text { products }(\mathrm{PP})\end{array}$ & $\begin{array}{l}\text { Próbki } \\
\text { Samples } \\
\text { n/n* }\end{array}$ & $\begin{array}{l}\text { Zakres zawartości } \\
\text { Range of contents }\end{array}$ & $\begin{array}{l}\text { Lit. } \\
\text { Ref. }\end{array}$ \\
\hline $\begin{array}{l}\text { Wielka Brytania } \\
\text { UK }\end{array}$ & $0,01 \mathrm{mg} / \mathrm{kg}$ & sosy sojowe & $369 / 264$ & $0,01-93,1 \mathrm{mg} / \mathrm{kg}$ & [31] \\
\hline USA & $0,005 \mathrm{mg} / \mathrm{kg}$ & sosy sojowe i PP & $55 / 18$ & $2,40-876,0 \mathrm{mg} / \mathrm{kg}$ & {$[31,39]$} \\
\hline Japonia / Japan & - & sosy sojowe & $22 / 7$ & $\mathrm{LoD}-0,009 \mathrm{mg} / \mathrm{kg}$ & {$[38]$} \\
\hline Chiny / China & $<5 \mu \mathrm{g} / \mathrm{kg}$ & $\begin{array}{l}\text { sosy sojowe } \\
\text { sosy sojowe z HVP }\end{array}$ & $629 / 629$ & $\begin{array}{c}0,005-189 \mathrm{mg} / \mathrm{kg} \\
0,01-117,7 \mathrm{mg} / \mathrm{kg}\end{array}$ & $\begin{array}{l}{[34]} \\
{[34]} \\
\end{array}$ \\
\hline Tajwan / Taiwan & $0,01 \mu \mathrm{g} / \mathrm{ml}$ & sosy sojowe & $214 / 104$ & $0,01-10,0 \mathrm{mg} / \mathrm{kg}$ & {$[6]$} \\
\hline $\begin{array}{l}\text { Korea Płd. } \\
\text { South Korea }\end{array}$ & - & sosy sojowe & $72 / 69$ & $<0,3-3,13 \mathrm{mg} / \mathrm{kg}$ & [27] \\
\hline Singapur / Singapore & $0,01 \mathrm{mg} / \mathrm{kg}$ & sosy sojowe & $317 / 44$ & $<0,01-3,0 \mathrm{mg} / \mathrm{kg}$ & {$[56]$} \\
\hline Australia & $0,01 \mathrm{mg} / \mathrm{kg}$ & sosy sojowe i ostrygowe & $39 / 18$ & $0,01-150 \mathrm{mg} / \mathrm{kg}$ & {$[31]$} \\
\hline Malezja / Malaysia & - & sosy sojowe & $5 / 1$ & $\mathrm{LoD}-0,005 \mathrm{mg} / \mathrm{kg}$ & {$[38]$} \\
\hline Brazylia / Brazil & $0,9 \mu \mathrm{g} / \mathrm{kg}$ & $\begin{array}{l}\text { sosy sojowe } \\
\text { sosy sojowe z HVP }\end{array}$ & $\begin{array}{c}35 / 3 \\
4 / 4 \\
\end{array}$ & $\begin{array}{l}\text { LoD }-663 \mu \mathrm{g} / \mathrm{kg} \\
144-4405 \mu \mathrm{g} / \mathrm{kg} \\
\end{array}$ & $\begin{array}{l}{[53]} \\
{[53]} \\
\end{array}$ \\
\hline Tajlandia / Thailand & - & sosy sojowe & $12 / 6$ & $0,005-0,03 \mathrm{mg} / \mathrm{kg}$ & {$[38]$} \\
\hline Austria & - & sosy sojowe i PP & $316 / 130$ & $\mathrm{LoD}-104,0 \mathrm{mg} / \mathrm{kg}$ & {$[31]$} \\
\hline Bułgaria / Bulgaria & $2,3 \mu \mathrm{g} / \mathrm{kg}$ & sosy sojowe & $21 / 21$ & $3,7-185,6 \mu \mathrm{g} / \mathrm{kg}$ & {$[7]$} \\
\hline Dania / Denmark & - & sosy sojowe i PP & $43 / 27$ & $\mathrm{LoD}-90,0 \mathrm{mg} / \mathrm{kg}$ & {$[31]$} \\
\hline Finlandia / Finland & - & sosy sojowe i PP & $103 / 53$ & LoD - $145 \mathrm{mg} / \mathrm{kg}$ & {$[31]$} \\
\hline Francja / France & - & sosy sojowe i PP & $73 / 39$ & LoD - $145 \mathrm{mg} / \mathrm{kg}$ & [31] \\
\hline Hiszpania / Spain & $0,001 \mu \mathrm{g} / \mathrm{ml}$ & sosy sojowe & $5 / 5$ & $0,28-20 \mu \mathrm{g} / \mathrm{kg}$ & [33] \\
\hline \begin{tabular}{|l|} 
Holandia \\
Netherlands \\
\end{tabular} & 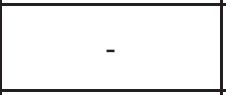 & sosy sojowe i PP & $273 / 77$ & LoD - 108 mg/kg & {$[31]$} \\
\hline Irlandia / Ireland & - & sosy sojowe i PP & $178 / 47$ & LoD - $1779 \mathrm{mg} / \mathrm{kg}$ & [31] \\
\hline Niemcy / Germany & - & sosy sojowe i PP & $692 / 198$ & LoD - $158 \mathrm{mg} / \mathrm{kg}$ & {$[31]$} \\
\hline \begin{tabular}{|l|l|}
$\begin{array}{l}\text { Norwegia } \\
\text { Norway }\end{array}$ \\
\end{tabular} & - & sosy sojowe i PP & $51 / 47$ & LoD - $146 \mathrm{mg} / \mathrm{kg}$ & {$[31]$} \\
\hline Polska / Poland & $1,84 \mu \mathrm{g} / \mathrm{kg}$ & sosy sojowe & $9 / 9$ & $2,7-8,3 \mu \mathrm{g} / \mathrm{kg}$ & [18] \\
\hline Szwecja / Sweden & - & sosy sojowe i PP & $76 / 31$ & $\mathrm{LoD}-79,9 \mathrm{mg} / \mathrm{kg}$ & [31] \\
\hline
\end{tabular}

Objaśnienia / Explanatory notes:

$\mathrm{n}$ - liczba próbek / number of samples; $\mathrm{n}^{*}$ - liczba próbek zawierających 3-MCPD / number of samples containing 3-MCPD 
$\mathrm{W}$ tab. 2. przedstawiono przykładowe dane literaturowe dotyczące zawartości 3-MCPD w sosach sojowych. Podawane w literaturze zawartości chloropochodnych propandioli i propanolu w kwasowo hydrolizowanych białkach sojowych (HVP) są zdecydowanie większe niż w tradycyjnie produkowanych sosach sojowych. Ogólnie przyjęła się opinia, że białka sojowe kwasowo hydrolizowane zawierają przeciętnie $100 \div 800 \mathrm{mg} / \mathrm{kg} 3-\mathrm{MCPD}$, zawartość 2-MCPD w HVP sięga zwykle $10 \div 90 \mathrm{mg} / \mathrm{kg}$. W literaturze podawane są zróżnicowane zawartości 3-MCPD w HVP (19,4 $549 \mathrm{mg} / \mathrm{kg}$ [50], 1,66 $\div 27,5 \mu \mathrm{g} / \mathrm{g}$ [22], $798 \mu \mathrm{g} / \mathrm{kg}$ [18]. Dane z tab. 2. dotyczące zawartości 3-MCPD w sosach sojowych i produktach pochodnych są dyskutowane w publikacjach sygnalizowanych $\mathrm{w}$ tej tabeli jako źródło oraz w dużej części w pracy, którą przedstawili Lee i Khora [31].

\section{Podsumowanie}

Występowanie i zawartość 3-MCPD oraz innych chloropochodnych propanodioli i propanolu (2-MCPD, 1,2 i 2,3-DCP) w HVP i sosach sojowych są dokumentowane od 38 lat. Większość opublikowanych prac dotyczy zawartości 3-MCPD w sosach sojowych. 3-MCPD jest związkiem szkodliwym, określonym przez Międzynarodową Agencję Badań nad Rakiem (IARC) jako "możliwe, że kancerogenny - Grupa 2B". HVP i sosy sojowe są jak do tej pory jedynymi produktami spożywczymi, w stosunku do których istnieją ustanowione przez UE limity dopuszczalnej zawartości 3-MCPD.

Przedstawiony artykuł jest przeglądem literaturowym obejmującym prace poświęcone badaniu i oznaczaniu zawartości 3-MCPD w HVP i sosach sojowych opublikowane do końca 2015 roku. Scharakteryzowano tradycyjne i przyspieszone technologie produkcji sosów sojowych oraz omówiono ich właściwości chemiczne i skład ze szczególnym uwzględnieniem związków chemicznych determinujących właściwości sensoryczne. Sosy sojowe są tradycyjnymi wyrobami spożywczymi produkowanymi od wieków w krajach wschodniej Azji. W ostatnim czasie obserwuje się znaczący wzrost eksportu tych produktów do Europy, w tym do Polski. Stąd uzasadnione jest podanie istotnych informacji o tych wyrobach i zwrócenie uwagi na występowanie w nich związków szkodliwych, w tym chloropochodnych propanolu i propanodioli. Jest to tym bardziej uzasadnione, że produkty handlowe nie zawierają takich informacji na etykietach detalicznych opakowań handlowych. $Z$ drugiej strony należy podkreślić, że naukowe informacje literaturowe dotyczące zawartości 3-MCPD i związków pokrewnych w sosach sojowych konfrontowane ze zwyczajami żywieniowymi konsumentów nie powinny powodować obaw bezpośredniego zagrożenia zdrowotnego.

Praca zrealizowana $w$ ramach badań wtasnych Katedry Chemii, Wydziat Nauk o Żywności, Szkoła Główna Gospodarstwa Wiejskiego w Warszawie. 


\section{Literatura}

[1] Aaslyng M.D., Elmore J.S., Mottram S.: Comparison of the aroma characteristics of acid-hydrolyzed and enzyme-hydrolyzed vegetable proteins produced from soy. J. Agric. Food Chem., 1998, 46 (12), 5225-5231.

[2] Aaslyng M.D., Martens M., Poll L., Nielsen P.M., Flyge H., Larsen L.M.: Chemical and sensory characterization of hydrolyzed vegetable protein, a savory flavoring. J. Agric. Food Chem., 1998, 46 (2), 481-489.

[3] AOCS: Official Method Cd 29a-13 Approved 2013. 2-and 3-MCPD fatty acid esters and glycidol fatty acid esters in edible oils and fats by acid transesterification.

[4] Bęcalski A., Zhao T.X.M., Sit D.: Cyclohexanone/sulfonated polymer catalyst: A new simple derivatizing procedure for GC-MS determination of 2-and 3-monochloropropanediols. Food Energy Security, 2013, 2, 157-165.

[5] CAC/RCP 64-2008. Codex Alimentarius CAC/RCP. Code of practice for the reduction of 3Monochloropropane-1,2-diol (3-MCPD) during the production of Acid-HVPs and products that contain Acid-HVPs., 2008, pp. 1-7.

[6] Cheng W.-C., Chen H.-C., Lin Y.-P., Lee H.-F., Chang P.-C., Chou S.-S.: Survey on 3-monochloro1,2-propandiol (3-MCPD) contents of soy sauce products during fiscal year 2002 in Taiwan. J. Food Drug Anal., 2004, 12 (4), 336-341.

[7] Christova-Bagdassarian V., Tishkova J.A., Vrabcheva T.M.: 3-Monochloro-1,2-propandiol (3MCPD) in soy sauce from the Bulgarian market. Food Addit. Contam. Part B., 2013, 6, 163-167.

[8] Codex Alimentarius Commission, Joint FAO/WHO Food Standards Programme, Proposed Draft Codex Standard for soy sauce, CX/PFV 04/22/8 Add.1. Sept. 2004.

[9] Crews C., Hasnip S., Chapman S., Hough P., Potter N., Todd J., Brereton P., Matthews W.: Survey of chloropropanols in soy sauces and related products purchased in the UK in 2000 and 2002. Food Addit. Contam., 2003, 20 (10), 916-922.

[10] Davidek J., Velisek J., Kubelka V., Janicek G., Simicova Z.: Glycerol chlorohydrins and their esters as products of the hydrolysis of tripalmitin, tristearin and triolein with hydrochloric acid. Zeit. Lebensmitt. Unters. Forsch., 1980, 171, 14-17.

[11] Dayrit F.M., Ninonuevo M.R.: Development of an analytical method for 3-monochloropropane-1,2diol in soy sauce using 4-heptanone as derivatizing agent. Food Addit. Contam., 2004, 21 (3), 204209.

[12] Dubois M., Tarres A., Goldman T., Donaubauer A., Seefelder W.: Comparison of indirect and direct quantification of esters of monochloropropandiol in vegetable oil. J. Chromatogr. A., 2012, 1236, 189-201.

[13] Ermacora A., Hrncirik K.: A novel method for simultaneous monitoring of 2-MCPD, 3-MCPD and glycidyl esters in oil and fats. J. Am. Oil Chem. Soc., 2013, 90, 1-8.

[14] Feng J., Zhan X.-B., Zheng Z.-Y., Wang D., Zhang L.-M., Lin C.-C.: New model for flavour quality evaluation of soy sauce. Czech J. Food Sci., 2013, 31, 292-305.

[15] Fukushima D.: Industrialization of fermented soy sauce production centering about Japanese Shoyu. In: Industrialization of Indigenous Fermented Foods. Second Ed. Ed. K.H. Steinkraus. Marcel Dekker Inc., New York 2004, pp. 1-78.

[16] Fukutome N.: Soy sauces of Asia. Korea's use of ganjang. Food Culture, 2014, 24, 14-25.

[17] Fukutome N.: Soy sauces of Asia. Soy sauce usage in the Philippines, Thailand and Vietnam. Food Culture, 2015, 25, 14-21.

[18] Gawarska H., Sawilska-Rautenstrauch D., Starski A., Karłowski K.: Występowanie 3monochloropropano-1,2-diolu (3-MCPD) w produktach spożywczych. Roczn. PZH, 2009, 60 (3), 213-216.

[19] Haines T.D., Adlaf K.J., Pierceal R.M., Lee I., Venkitasubramanian P., Collison M.W.: Direct determination of MCPD fatty esters and glicidyl fatty acid esters in vegetable oils by LC-TOF-MS. J. Am. Oil Chem. Soc., 2011, 88, 1-14.

[20] Hamada T., Fukushima Y., Motai H.: Continuous production of soy sauce in a bioreactor. In: Applications of Biotechnology to Traditional Fermented Foods. National Academy Press, 
Washington, D.C., USA, 1992, pp. 114-118.

[21] Hori K., Koriyama N., Omori H., Kuriyama M., Arishima T., Tsumura K.: Simultaneous determination of 3-MCPD fatty acid and glicidol fatty acid esters in edible oils using liquid chromatography time-of-flight mass spectrometry. LWT - Food Sci. Technol., 2012, 48, 204-208.

[22] Huang M., Jiang G., He B., Liu J., Zhou Q., Fu W., Wu Y.: Deternination of 3-chloropropane-1,2diol on liquid hydrolized vegetable proteins and soy sauce by solid-phase microextraction and gas chromatography/mass spectrometry. Analytical Sciences, 2005, 21 (11), 1343-1347.

[23] IARC Monographs on the Evaluation of Carcinogenic Risks to Humans. Some chemicals present in industrial and consumer products, food and drinking water. Vol. 101. IARC, Lyon 2012, pp. 349374.

[24] Iwasaki K., Nakajima M., Sasahara H., Watanabe A.: Rapid ethanol fermentation for soy sauce production by immobilized yeast cells. Agric. Biol. Chem., 1991, 55 (9), 2201-2207.

[25] Jarunrattanasri A., Theerakulkait C., Cadwallader K.R.: Aroma components of acid-hydrolized vegetable protein made by partial hydrolysis of rice bran protein. J. Agric. Food Chem., 2007, 55 (8), 3044-3050.

[26] Jędrkiewicz R., Orłowski A., Namieśnik J., Tobiszewski M.: Green analytical chemistry introduction to chloropropanols determination at no economic and analytical performance costs. Talanta, 2016, 147, 283-288.

[27] Kim H.J., Ha J.H., Chun H.S., Cho E.J.: Estimation of daily exposure to 3-monochloropropane-1,2diol from commercial soy sauces in Korea. Food Sci. Biotechnol., 2006, 15, 768-772.

[28] Kowalska D., Gruczyńska E., Tarnowska K.: Estry chloropropanoli, chloropropanodioli i glicydolu - termicznie indukowane procesowe zanieczyszczenia żywności. Problemy Hig. Epidemiol., 2017, 98 (1), 9-16.

[29] Kowalska D., Gruczyńska E., Kowalska M., Kozłowska M., Kowalski B.: Chloropropanole, chloropropanodiole i ich estry w żywności. Żywność. Nauka. Technologia. Jakość, 2015, 4 (101), 5 20 .

[30] Kuhlmann J.: Determination of bound 2,3-epoxy-1-propanol (glicidol) and bound monochloropropanediol (MCPD) in refined oils. Eur. J. Lipid Sci. Technol., 2011, 113, 335-344.

[31] Lee B.Q., Khor S.M.: 3-Chloropropane-1,2-diol (3-MCPD) in soy sauce: A Review on the formation, reduction and detection of this potential carcinogen. Compr. Revs. Food Sci. Food Safety, $2015,14,48-66$

[32] Lee S.M., Seo B.C., Kim Y.-S.: Volatile compounds in fermented and acid hydrolyzed soy sauces. J. Food Sci., 2006, 71 (3), C146-C156.

[33] Leon N., Yusa V., Pardo O., Pastor A.: Determination of 3-MCPD by GC-MS/MS with PTV-LV injector used for a survey of Spanish foodstuffs. Talanta, 2008, 75, 824-831.

[34] Li S., Wu S., Chen Y.-H., Xu X.-R., Deng G.-F., Xia E.-Q., Zhou J., Li H.-B.: Source and analytical methods of chloropropanols in food. Intern. J. Food Nutr. Safety, 2012, 1 (3), 107-119.

[35] Luh B.S.: Industrial production of soy sauce. J. Ind. Microbiol., 1995, 14, 467-471.

[36] Macarthur R., Crews C., Davies A., Brereton P., Hough P., Harvey D.: 3-Monochloropropane-1,2diol (3-MCPD) in soy sauces and similar products available from retail outlets in the UK. Food Addit. Contam., 2000, 17 (11), 903-906.

[37] Mac Mahon S., Begley T.H., Diachenko G.W.: Occurrence of 3-MCPD and glycidyl esters in edible oils in the United States. Food Addit. Contam., Part A - Chem. Anal. Control. Expo. Risk. Assess., 2013, 30, 2081-2092.

[38] New Zealand Ministry of Agriculture and Forestry. Survey of chloropropanols in soy sauce. MAF NZ Standards, June 2011. [online]. Dostęp w Internecie [20.11.2016]: http://www.foodsafety.govt.nz/industry/importing/monitoring-and-review/surveys.htm

[39] Nyman P.J., Diachenko G.W., Perfetti G.A.: Survey of chloropropanols in soy sauces and related products. Food Addit. Contam., 2003, 20, 909-915.

[40] OEHHA: Proposition 65List. Chemicals known to the state to cause cancer or reproductive toxicity. May 11, 2015.

[41] Rozporządzenie Komisji (UE) nr 1881/2006 r. ustalające najwyższe dopuszczalne poziomy niektórych zanieczyszczeń w środkach spożywczych. Dz. U. UE, L 364 z 20.12.2006 s. 5. 
[42] Sano A., Satoh T., Oguma T., Nakatoh A., Satoh J.-I., Ohgawara T.: Determination of levulinic acid in soy sauce by liquid chromatography with mass spectrometric detection. Food Chem., 2007, 105 (3), 1242-1247.

[43] Shurtleff W., Aoyagi A.: History of soy sauce (160 CE to 2012). Soyinfo Center, Lafayette, California, USA, 2012.

[44] Sun X., Zhang L., Zhang H., Qian H., Zhang Y., Tang L., Li Z.: Development and application of 3chloro-1,2-propandiol electrochemical sensor based on a polyaminothiophenol modified molecularly imprinted film. J. Agric. Food Chem., 2014, 62 (20), 4552-4557.

[45] Sun S.Y., Jiang W.G., Zhao Y.P.: Profile of volatile compounds in 12 Chinese soy sauces produced by a high-salt-diluted state fermentation. J. Inst. Brewing, 2010, 116 (3), 316-328.

[46] Steinhaus P., Schieberle P.: Characterization of the key aroma compounds in soy sauce using approaches of molecular sensory science. J. Agric. Food Chem., 2007, 55, 6262-6269.

[47] Tachi H.: Characteristics of Japanese soy sauce. Food Culture, 2015, 25, 3-4.

[48] Tomar R.S., Tsai F.C., Sandy M.S.: Evidence of the carcinogenicity of 3-monochloropropane-1,2diol (3-MCPD). OEHHA. Sept. 2010, pp. 1-38.

[49] Tseng Y.L., Lee Y.L., Li R.C., Mau J.L.: Non-volatile flavor components of Ganoderma tsugae. Food Chem., 2005, 90, 409-415.

[50] Van Bergen C.A., Collier P.D., Cromie D.D.O., Lucas R.A., Preston H.D., Sissons D.J.: Determination of chloropropanols in protein hydrolysates. J. Chromatography, 1992, 589, 109-119.

[51] Velisek J., Davidek J., Haislova J., Kubelka V., Janicek G., Mankova G.: Chlorohydrins in protein hydrolyzates. Zeit. Lebensmitt. Unters. Forsch., 1978, 167, 241-244.

[52] Velisek J., Davidek J., Kubelka V., Bartosova J., Tuckova A., Hajslova J., Janicek G.: Formation of volatile chlorohydrins from glycerol (triacetin, tributyrin) and hydrochloric acid. LebensmittelWissenschaft Technol., 1979, 12, 234-236.

[53] Vicente E., Arisseto A.P., Furlani R.P.Z., Monteiro V., Goncalves L.M., Pereira A.L.D., Toledo M.C.F.: Levels of 3-MCPD in selected processed foods from the Brazilian market. Food Res. Int., 2015, 77 (3), 310-314.

[54] Wang H., Jenner A.M., Lee C.Y., Shui G., Tang S.Y., Whiteman M., Wenk M., Halliwel B.: The identification of antioxidants in dark soy sauce. Free Radical Res., 2007, 41 (4), 479-488.

[55] Weber J.V., Sharypov V.I.: Ethyl carbamate in foods and beverages: A review. Environ. Chem. Lett., 2009, 7 (3), 233-247.

[56] Wong K.O., Cheong Y.H., Seah H.L.: 3-Monochloropropane-1,2-diol (3-MCPD) in soy and oyster sauces: Occurrence and dietary intake assessment. Food Control, 2006, 17, 408-413.

[57] Xu X., Ren Y., Wu P., Shen X., Han J., Feng X.: The simultaneous separation and determination of chloropropanols in soy sauce and other flavoring with gas chromatography-mass spectrometry in negative chemical and electron impact ionization modes. Food Addit. Contam., 2006, 23 (2), 110 119.

[58] Xu X.-M., Wu H.-W., He H.-L., Huang B.-F., Han J.-L., Ren J.-P.: Study of chloropropanols in soy sauce by gas chromatography triple quadrupole mass spectrometry with coupled column separation without derivatisation. Food Addit. Contam.., Part A, 2013, 30, 421-429.

[59] Yanfang Z., Wenyl T.: Flavour and taste compounds analysis in Chinese solid fermented soy sauce. African J. Biotechnol., 2009, 8 (4), 673-681.

[60] Zalecenie Komisji z dnia 10 września 2014 r. w sprawie monitorowania występowania w żywności 2- i 3-monochloropropano-1,2-diolu ( 2- i 3-MCPD), estrów kwasów thuszczowych 2- i 3- MCPD oraz estrów glicydowych kwasów tłuszczowych. Dz. Urz. UE, L 271/93. (2014/661/UE Tłumaczenie na język polski). 


\title{
CONTENT OF CHLOROPROPANEDIOLS IN ACID HYDROLYSATES OF VEGETABLE PROTEINS AND IN SOY SAUCES
}

\author{
$\mathrm{S}$ u m m a r y
}

In many Asian countries, soy sauces are traditional products that have been used for ages as aromatic and flavouring spices added to foods during their manufacture; they are also used as table condiments applied at the individual discretion of consumers. The annual world production of soy sauces amounts to over 10 billion (bn) litres ( $10 \mathrm{~m}$ tonnes). China is the largest producer of soy sauces ( $5 \mathrm{~m}$ tonnes) and their main exporter (over 94 thousand tonnes). Currently, soy sauces are reported to expand into the European and American markets. Two main groups of methods are applied to produce soy sauces: fermentation processes and procedures based on acid-hydrolysis of proteins. The production of soy sauces using the traditional (fermentation methods) technologies is time consuming and, thus, expensive. So, the technologies have been developed, which consist in the 'accelerated' fermentation or utilize semi-synthetic materials (HVP acid-hydrolyzed vegetable proteins). At the turn of $1970 \mathrm{~s}$ and $1980 \mathrm{~s}$ in the $20^{\text {th }}$ century, 3-monochloropropane-1,2-diol (3-MCPD) were found in HVP and in HVP-based soy sauces, and, later, 2-MCPD, dichloropropanols (DCP), and esters of chlorinated propanediols and propanol with fatty acids. Those compounds are harmful to health and, if eaten in larger quantities, they induce carcinogenic changes, kidney diseases, and reproductive disorders. In this research study, a review of reference literature is presented on the production of soy souses. The objective of the review was to compile information on the production technologies of soy sauces. In particular, the occurrence of 3-MCPD was highlighted. Law regulations were discussed as were the analytical methods of determining 3-MCPD.

Key words: HVP, acid hydrolysates of proteins, soy sauce, chloropropanediols, chloropropanols, 3-MCPD 